Принимая во внимание все выше перечисленные результаты исследований и выводы, сделанные педагогами, возникает необходимость в специальной целенаправленной логопедической работе по формированию эмоционально-оценочной лексики у старших дошкольников с общим недоразвитием речи.

$$
* * *
$$

1. Базжина, Т.В. Психолингвистический анализ некоторых этапов доречевого периода [Текст] / Т.В. Базжина // Становление речи и усвоение языка ребенком. - М.: Изд-во МГУ, 1985. - С. 6- 20.

2. Галкина-Федорук, Е.М. Современный русский язык. Лексика. (Курс лекций) [Текст] / Е.М. Галкина-Федорук. - Издательство Московского университета, 1954. - 202 с.

3. Дель, С.В. Особенности овладения эмоциональной лексикой [Текст] / С.В. Дель, Д.В. Нечаева // Логопед в детском саду. - 2011. - №3. - С. 5-12.

4. Кондратенко, И.Ю. Выявление и преодоление речевых нарушений в дошкольном возрасте [Текст]: метод. пособие / И.Ю. Кондратенко. - М.: Айрис-пресс, 2005. - 224 с.

5. Мамушин, В.В. Анализ слов качественной оценки в письменной речи пятиклассников [Текст] / В.В. Мамушин // Вопросы изучения лексики русского языка в восьмилетней школе. - Известия АПН РСФСР, 1962. - №124. - С. 131 - 183.

6. Марцун, Н.С. Особенности эмоционально-оценочной лексики детей старшего дошкольного возраста с общим недоразвитием речи / Н.C. Марцун // IV Машеровские чтения: материалы междун. научно-практич. конф. студ., аспир. и молод. ученых, Витебск, 28-29 октября 2010 г. / Витебский гос. университет; редкол.: А.П. Солодков (гл. ред.). - Витебск: УО «ВГУ имени П.М. Машерова», 2010. - T.II. - C. $352-353$.

7. Минаева, В.М. Развитие эмоций дошкольников. Занятия. Игры. Пособие для практических работников дошкольных учреждений [Текст] / В.М. Минаева. - М.: АРКТИ, 2003. - 48 с.

8. Яшина, В.И. Овладение эмоционально-оценочной лексикой старшими дошкольниками [Текст]: Монография / В.И. Яшина, Е.А. Ставцева. - М.: Прометей, 2016. - 190 с.

9. Константинова, Е.А. Особенности эмоциональной лексики у дошкольников с заиканием // Царскосельские чтения // СПб.: ГАОУ ВО ЛО «ЛГУ им. А.С. Пушкина», 2017. С. 34 - 38. [Электронный ресурс]. Системные требования: Adobe Acrobat Reader. Режим доступа: https://cyberleninka.ru/journal/n/tsarskoselskie-chteniya?i=975112 (дата обращения: 05.01.2021)

\title{
Воронова А.A. \\ Роль игры в анимационных технологиях с детьми и подростками
}

\section{Самарский государственный институт культурь}

(Россия, Самара)

doi: $10.18411 / \mathrm{j}-05-2021-222$

\section{Аннотация}

В статье предпринята попытка обоснования ключевой роли анимационной деятельности при работе с детьми и подростками. Автор рассматривает понятие анимации, характеристики игры в анимационных технологиях и ее место в организации анимационных программ для детей и подростков при решении образовательных задач. Подчёркивается, что включение анимационных мероприятий в школьную программу даёт возможность задействовать творческий потенциал обучающегося.

Ключевые слова: анимация, анимационная деятельность, дети, подростки, игра, анимационные технологии, школьники.

\section{Abstract}

The article attempts to substantiate the key role of animation activity when working with children and adolescents. The author examines the concept of animation, the characteristics of the game in animation technologies and its place in the organization of animation programs for children and adolescents in solving educational problems. It is emphasized that the inclusion of animation activities in the school curriculum makes it possible to use the creative potential of the student.

Key words: animation, animation activity, children, adolescents, game, animation technologies, schoolchildren. 
В последние годы детские и молодежные образовательные, творческие, досуговые учреждения все чаще обращаются к анимационным технологиям. Это связано отчасти с развитием новых возможностей для обучения и развития детей и подростков. Актуальность темы подтверждается и тем, что современному ребенку становятся необходимы анимационные элементы для обучения и самообучения в том числе. С технологическим прогрессом и развитием интернета современные дети активнее и эффективнее изучают предметы, узнают новое именно благодаря анимационной игре.

Во второй половине XX в. термин «анимация» получил еще одно определение и стал применяться с художественным смыслом: как деятельность по созданию мультфильмов. К концу $\mathrm{XX}$ в. и в наше время анимация представляет собой самостоятельное направление психолого-педагогической деятельности в сфере культурного и образовательного процесса [2, с. 115].

Как утверждал Уолт Дисней, «анимация может объяснить все, что может вообразить человеческий разум. Это средство делает его наиболее универсальным и понятным средством коммуникации, разработанным для быстрого массового признания». Игра в анимации - одна из самых важных частей при обучении детей независимо от их возраста, способ общения [4, с. 2]. Игра, как никакая другая деятельность, позволяет самостоятельно создавать те или иные модели социальнокультурной коммуникации. Сегодня дети хорошо оснащены для использования любых технологий, они начинают разрабатывать свой собственный способ повествования, а это означает, что началась эра цифрового повествования, цифровой игры. Дети в возрасте до семи лет часто обнаруживают, что использование цифровых инструментов и технологий - лучший способ для них выразить свое творчество. Создавая истории с использованием цифрового оборудования, они теперь могут охватить более широкую аудиторию и выразить себя не только с помощью собственного голоса, но и визуально. Можно отметить, что анимация, таким образом, вступила в дошкольное образование [1, c. 98].

Игра - важное средство эмоционального, интеллектуального и физического развития ребёнка. Игровая деятельность влияет на формирование характера, мировосприятия и отношений с окружающими, способствует зарождению чувства юмора, которое у детей появляется достаточно поздно. Анимация - это одновременно педагогический инструмент и форма повествования, как физического, так и цифрового. Анимационная деятельность на сегодняшний момент актуальна для многих педагогов, стремящихся улучшить и повысить профессиональный уровень [5, с. 46]. Учителя используют игру в анимационных технологиях как способ задействовать детское воображение, и через воображение помочь детям учиться по разным предметам, будь то математика, естественные науки, история или искусство. Когда цифровое повествование используется для обучения математике, например, дети могут расширять свой математический словарный запас, сравнивая различные картинки, снимки или сцены.

Игра в анимации может использоваться как промежуточное звено между традиционными методами обучения и современным способом установления контакта с детьми цифровой эпохи. Создание цифровой истории мотивирует детей и подростков оценивать свои когнитивные и поведенческие навыки, поскольку они должны быть внимательны к другим. Также игра в анимации дает детям и подросткам возможность продемонстрировать свои способности лидерству.

Стоит отметить, что в России анимационная сфера в детско-юношеской среде стала очень популярна, а детские анимационные программы прочно вошли в досуговую и образовательную деятельность всех учреждений. При планировании анимационных программ аниматор учитывает различные цели: от формирования позитивного настроения и самочувствия до задач самоактуализации и самореализации, что 
невозможно без владения педагогическими и психологическими знаниями и умениями $[4$, c. 35].

Игра - это ключевая составляющая анимационных программ, она актуальна и востребована во всех возрастах. В процессе игры формируются навыки самоограничения и самоопределения, поэтому можно считать, что игра - это отличный шанс узнать и раскрыть свои возможности. Так, детям младшего возраста свойственны эмоциональность, стремление к массовым действиям, склонность к подражанию, поэтому, исходя из этих психологических особенностей, определяется основной метод анимационного взаимодействия. В числе популярных форм анимационной деятельности по содержанию стоит отметить «интерактивы» - специальные мероприятия, в которых дети вовлекаются в массовые игры. Метод игры занимает в работе с младшими школьниками ведущее место [3, с. 5].

Стремление детей к новым знаниям и навыкам намного эффективнее идет через игру в рамках анимационных программ. В процессе взросления дети начинают осознавать свое «Я», у них формируются основы личности и жизненное кредо. Поэтому всякое взаимодействие в процессе анимационных технологий дает хороший толчок для правильного, гармоничного становления личности.

Активное участие детей и подростков в анимационных программах дает им прекрасную возможность развить творческую активность, инициативность, снять внутреннее напряжение, скованность, что ведет к формированию и совершенствованию разнообразных детских способностей [6, с. 11].

Использование анимации в обучении дает детям понимание разницы между фактами и вымыслом. Поддерживая идеи детей и их право на самовыражение, учитель помогает развивать их критический взгляд на цифровые медиа. В большинстве случаев использование игры в анимационных технологиях вызывает интерес у детей и увлечение учебной деятельностью растет у них. Использование анимации в качестве формы обучения может быть достаточным только в том случае, если учитель свободно владеет технологическими инструментами, поскольку реализация предметных задач в цифровом и физическом повествовании может быть достаточно сложной.

Традиционные способы, например, чтение лекций с использованием учебников и классных досок иногда действительно не передают всей сути лекции, а порой это утомляет школьников. Если прочитать ту же лекцию с использованием анимационных элементов, то эффект восприятия информации будет намного положительнее. Анимация сегодня - это не только игры и развлечения в офлайн, это еще и многообразные онлайн инструменты.

Одна из причин, по которой анимация теперь так широко распространена, заключается в том, что многие люди считают, что анимация может помочь учащимся легче понять сложные идеи. Процесс преподавания и обучения приобретает совершенно новый опыт, когда в процессе задействованы анимационные технологии.

При отборе игр для анимационной программы, аниматор руководствуется различными критериями, так как незнание изначальных, заданных обстоятельств для игры может сделать времяпровождение менее плодотворным, чем хотелось бы.

Критерии отбора игр в анимационных не цифровых программах таковы:

- назначение анимации;

- возраст участников (психические и эмоциональные особенности, специфика восприятия жизни и типичные поведенческие проявления, состояние организма и физические возможности);

- количество участников анимационного мероприятия;

- погодные условия;

- место и условия проведения анимационной программы (закрытое помещение, открытое пространство);

- доступность и разнообразие инвентаря. 
Среди множества источников интереса детей к процессу изучения языка игры кажутся очень важными. Очевидно, есть много других источников, таких как рисунки и рассказы. Картинки служат визуальным стимулом, в то время как игры используют как зрительные, так и слуховые каналы и активируют языковое производство, а иногда и физические движения.

Юные ученики любят играть, они участвуют в игре с большим энтузиазмом и желанием, чем в любой другой задаче в классе. Тем не менее, игры иногда воспринимаются как развлекательная деятельность, которой дети на самом деле не учатся. Есть учителя, которые не осознают важность игр, считая их не богатством различных приемов и возможностью реального общения, а неконтролируемой и шумной тратой времени. Однако в целом дети учатся лучше, когда они активны. Таким образом, когда обучение превращается в увлекательную игру, они очень часто готовы вкладывать в нее много времени и усилий. Более того, с учетом разнообразия стилей обучения и предпочтений, которые демонстрируют учащиеся, выгоды от игр, кажется, устраивают всех, поскольку для детей игровая деятельность гораздо более насыщена изучением языка, чем выполнение других видов практики. Если игры правильно спроектированы, они могут стать отличной и важной частью детской учебной программы.

Все дети рождаются с творческими способностями, однако в процессе жизни они могут бездействовать, а анимация способна раскрыть эти таланты. Технологии анимации могут использоваться как актив, позволяющий сохранить творческий потенциал и развить его. Исследования неоднократно подтверждали, что анимация способна стимулировать мышление, а в результате группового обсуждения, которое происходит в процессе игры, может улучшить формирование идей и критического мышления у детей и подростков. Анимация сочетает в себе творческие способности и учёбу, что помогает детям развить критическое и аналитическое мышление.

Эмоциональные, социальные навыки, навыки самовыражения и сотрудничества - это лишь некоторые из важных навыков, которые осваиваются детьми в процессе анимационных игр. Анимация в формате игры может обогатить игровые возможности детей, что, в свою очередь, повышает социальные и когнитивные требования и может рассматриваться как положительная сила для детского развития.

Игра в анимации - это, прежде всего, выполнение познавательной функции. В этой роли анимация предназначена для поддержки когнитивных процессов учащихся, которые в конечном итоге приводят к пониманию предмета. Кроме того, юное поколение, увлечённое анимацией и анимационными рассказами, увлечённо принимает возможность создавать свои собственные анимационные идеи. Творческий потенциал анимации огромен, и включение анимационных мероприятий в школьную программу даёт возможность задействовать этот потенциал для решения ряда образовательных задач.

Многие современные педагоги стремятся научить детей навыкам анимации. Успешное использование анимации в обучении происходит на основе предшествующих знаний в предметной области. В дополнение к предметным знаниям дети должны полностью понимать технологии и программы, которые они собираются использовать.

В подростковом возрасте происходит ряд когнитивных, эмоциональных, физических изменений, которые составляют основу для развития личности. Подростки находятся на важном переходном этапе, когда они естественным образом пытаются освободиться от своих родителей и вместо этого ищут новые способы делать что-то для себя. Впервые подростки начнут рассматривать группы друзей и сверстников как более важные и влиятельные, чем их родители, что часто приводит к конфликтам.

Таким образом, какими бы трудными ни были сложившиеся ситуации, подросткам необходимо дать время и пространство, чтобы они могли принимать 
решения самостоятельно и учиться на своих ошибках. Игра в этой цепочке имеет колоссально важное значение. Роль игры в анимационных программах для подростков огромна: она помогает развить такие навыки, как сочувствие, обмен мнениями и лидерство, а также положительно влияет на них с точки зрения академической мотивации и устремлений. В этом возрасте необходимо поддерживать открытый диалог, и очень важно, чтобы ребенок чувствовал себя способным рассказать Вам о своём новом опыте и проблемах.

Растущее число новых технологий ставит учителей в положение, где они вынуждены постоянно развиваться и создавать интересные методы обучения с новыми технологиями, и как один из наиболее обсуждаемых способов преподавания и обучения, анимация становится все более актуальной. Учебная среда, основанная на анимационных технологиях, приобретает с каждым годом все более важное значение.

$$
* * *
$$

1. Бахтина И. Активные методы обучения / И. Бахтина // Сестринское дело. - 2008. - № 4. - С. 20 -21.

2. Ганьшина Г.В., Шляпина Е.Д. Формирование лидерских качеств подростков средствами социально-культурной анимации // Современные наукоемкие технологии. Москва: - 2016. - 127 с.

3. Кравчук Т.А. Анимационные мероприятия спортивной направленности: Психология и педагогика: методика и проблемы практического применения. - 2016. - 152 с.

4. Матенева В. П. Социально-культурная коммуникация в процессе игровой деятельности // Научнометодический электронный журнал «Концепт». - 2016. - № S14. - C. 36-39. - URL: http://ekoncept.ru/2016/76170.htm.

5. Проценко Е.Г., Чигринова В.А. Роль анимационной деятельности в обучении подростков Рецензируемый научный журнал «Тенденции развития науки и образования». Январь 2021 г. № 69, Часть 5, Изд. НИЦ «Л-Журнал», 2021. - С. 45-48.

6. Фисюк Т.Т. Проявление феномена анимации в технологии организации культурно-досуговых программ // Ученые записки Алтайской государственной академии культуры и искусства. - 2018. $-149 \mathrm{c}$.

\section{Гирина А.Н., Ампилогов И.А. \\ Заинтересованность студентов к предоставляемой информации в процессе обучения}

Оренбургский государственный университет (Россия, Оренбург)

doi: $10.18411 / \mathrm{j}-05-2021-223$

\section{Аннотация}

В профессиональной подготовке специалистов любого профиля актуальной является проблема заинтересованности студента к предоставляемой информации. В статье показан алгоритм изложения информации, за счет которого происходит доступное изложение материала и способ заинтересовать студента предоставляемой информацией. Решение этой задачи, по нашему мнению, возможно при постоянном мотивационном обеспечении учебного процесса и связи обучения с практикой. Целью данного исследования является отображение использования полученной информации в учебном процессе и на практике. В исследовании использовались общенаучные и специальные методы: наблюдение, сравнение, синтез, анализ. Результат исследования заключается в выделении основных преимуществ использования методов изложения материала, преподносимого студенту в процессе преподавания, с целью заинтересованности к предоставляемой информации. Практическая значимость данной работы состоит в том, что мы показываем, как правильно структурировать материал, чтобы заинтересовать студентов к предоставляемой информации. Разработан программный инструмент для извлечения отзывов об интересующих событиях.

Ключевые слова: информация, масс медиа, поисковые системы, платформа микроблогинга Twitter. 